\title{
The Abundance and Distribution of Invertebrates and Relation to Macrophyte Communities in Intertidal Zone of Shatt Al-Arab River, Basrah, Iraq
}

\author{
Khaled Kh Al-Khafaji ${ }^{1 *}$, Khadija K Hreeb ${ }^{1}$, Anfas N Akash ${ }^{2}$ and Amal S Al-Shara ${ }^{1}$ \\ ${ }^{1}$ Marine Biology Department, Marine Science Centre, Iraq \\ ${ }^{2}$ Ecology Department, University of Basrah, Iraq
}

Submission: October 27, 2017; Published: February 12, 2018

*Corresponding author: Khaled Kh Al-Khafaji, Marine Biology Department, Marine Science Centre, Iraq, Email: khaledalkhafaji70@gmail.com

\begin{abstract}
The samples were collected once in three months during 2015 from intertidal zone of Shatt al-Arab River from eight sampling sites. For the purpose of evaluating the spatial and seasonal variations in the diversity, density and abundance of invertebrates in relation to diversity of Aquatic plant and related the dynamics of water temperature, salinity, water transparency, $\mathrm{pH}$, dissolved oxygen, phosphate and nitrate. The diversity and distribution patterns of certain invertebrate's species were clearly related to plants and water quality as evident from the present study.

In the present study tried to assess indices invertebrate species as Shannon-Weaver index, Simpson's index, and Index of Evenness species in eight sites at Shore of Shatt Al- Arab River and predict the state of water according to species and physicochemical parameters. The indices were evaluated at individual species level and varied species to species. In the study 37 invertebrate species from two phylum and five classes were observed. The Annual density of Arthropoda and Mollusca were $61.32 \%$ and $38.68 \%$ respectively. The class wise densities were as Bivalve (1.22\%), Insecta (4.27\%), Malacostraca (27.50\%), and Maxillopoda (29.52\%), Gastropoda (37.46\%).
\end{abstract}

Keywords: Invertebrates; Macrophyte; Intertidal zone; Shatt Al-Arab

\section{Introduction}

Aquatic invertebrates are important components of aquatic food web. They act as decomposers, detritus, an indicator and primary food for others. Benthic invertebrates have been attractive targets of biological monitoring efforts because they are a diverse group of long-lived, sedentary species that react strongly and often, predictably to human influence on aquatic ecosystems [1]. Macroinvertebrates and water quality are interrelated to each other, as macroinvertebrates are a potential indicator of water quality [2]. They are most frequently used in biomonitoring studies because the responses of macroinvertebrates to organic and inorganic pollution have been extensively documented [3].

A number of studies have compared the ability of different species of macrophytes to support varying densities of invertebrate communities [4-10]. These studies showed that the abundance and distribution of invertebrates varies greatly over time and that some plants support greater numbers, higher diversity, and greater biomass of organisms than others $[5,6,9]$. The surface area of the plant and the leaf morphology may have an important effect on a plant's ability to support macroinvertebrates [5] and chemicals secreted by the plants may also be a factor influencing the total possible number of invertebrates present [6]. [11] noted that those communities with higher plant surface area tended to support larger invertebrate populations.

Recent studies on the biodiversity of the shatt al arab river. Most recent published research papers and reports dealt mostly with one group of organisms in one type of the Shatt Al- Arab river, like Al-Obaidi [12] on phytoplankton, Ali et al. [13] on macroinvertebrates, Habeeb [14] on waterfowls, Mohamed et al. [15] Hussain et al. [16], 2009 on fishes, Al-Abbawy (2009) on macrophytes, Qazar (2009) on gastropod and Abd (2010) on phytoplankton and fishes and Salman et al. [17] on zooplankton. Few comprehensive reports of IMRP (2006), ARID (2006) and IMET (2006) dealt with several main biological groups performed in three major Southern marshes or more.

Dudgeon et al. [18] indicated that water flow modifications was one of five reasons affected freshwater biodiversity including over exploitation, water pollution, habitat degradation and invasion of alien and exotic species. 
Recent studies on the biodiversity of the shatt al arab river and southern marshes. Most recent published research papers and reports dealt mostly with one group of organisms in one type of the Shatt Al- Arab river, like Hassan et al. [14] on relation between insects diversity and population of algae, Al-Obaidi [12] on phytoplankton, Ali et al. [13] on macroinvertebrates, Naser et al. [15] on gastropod and Salman et al. [17]on zooplankton.

Dudgeon et al. [18] indicated that water flow modifications was one of five reasons affected freshwater biodiversity including over exploitation, water pollution, habitat degradation and invasion of alien and exotic species.

The aim of this paper is to detect a possible relationship between invertebrates and plant species richness. Such a relationship is of particular interest in evaluating sites of conservation importance where often only vegetation data are available. A positive correlation between plant and invertebrate species richness would result in sites chosen for conservation management.

The aim of this paper is to detect a possible relationship between invertebrates and plant species richness. Such a relationship is of particular interest in evaluating sites of conservation importance where often only vegetation data are available. A positive correlation between plant and invertebrate species richness would result in sites chosen for conservation management.

And this study was done to find out the spatial and temporal variation in diversity and distribution pattern in invertebrates in the intertidal at shore of shatt al- arab river so as to estimate the diversity and indices as Shannon-Weaver index, Species richness, Simpson's index, and Index of evenness.

\section{Study Area}

Consists Shatt al-Arab from the confluence of the Tigris and Euphrates in the town of Qurna, with a length of the area to meet up to its mouth in the Gulf about $195 \mathrm{~km}$ and ranges prone than 500 meters at the city of Basra of more than $2 \mathrm{~km}$ at the Faw city has narrowed in certain places for up to 200 meters, brackish water for mixing water with water Gulf salty and it features aggregates plant and animal Shatt al-Arab and distinguish them from the totals inland waters and environment Arabian Gulf Marine [19].

Selected eight sampling stations along the Shatt al- Arab, depending on the differences in the characteristics in terms of nutrients resulting from agricultural activities and human resources of the surrounding areas as well as feature densities and diversity of aquatic plants and its presence throughout the study period. The station

I. Is the first near the Qurna city north of the province of Basra.

II. Station in Deheer near the bridge link to the banks of the city either.
III. The station is shore of Sindibad Island north of the province of Basra.

IV. The station is Gharmat Ali river at Gharmat Ali University north of Basrah.

V. Station located in Marsa al- Musahb south of Hamar Marsh.

VI. The station in the district of Shatt al- Arab at the entrance to the River Salyhia against the teaching hospital.

VII. Station is site at shore of Abu Al-Khaseb, station in shore of siba city (Figure 1).

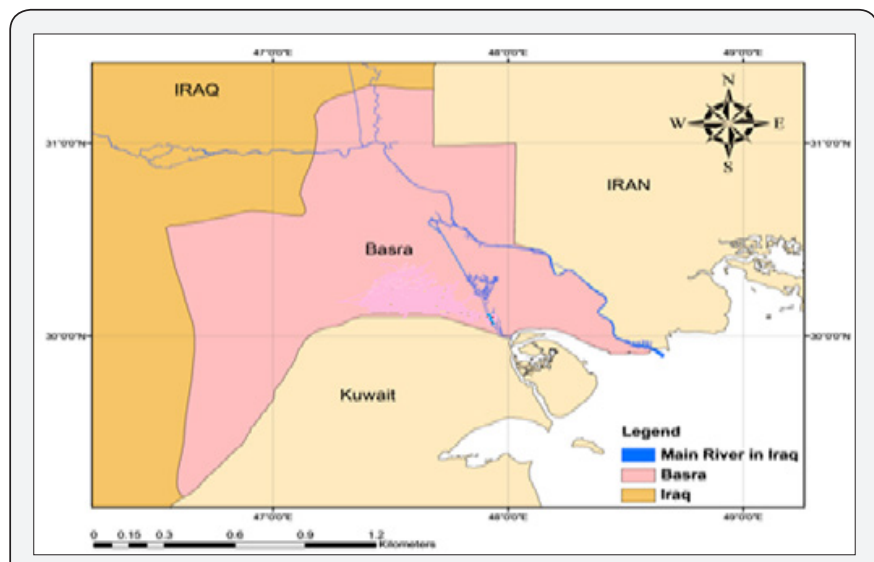

Figure 1: Map of study sites.

\section{Materials and Methods}

\section{Samples Collection and Identification}

Aquatic invertebrates were collected from eight sites during period from January to December 2015, Mud samples of one liter were collected from the bottom using an Ekman's grab and the samples were preserved in $9 \%$ formaldehyde. Ekman dredge (50X20 $\mathrm{cm} \times 0.5 \mathrm{~mm}$ mesh) has been used to collected and measured the density of invertebrates samples from all sites through the period of study, and preserved in $80 \%$ alcohol.

These species of organisms were sorted and identified using articles [20-22]. And aquatic plants were identified using articles [23]. Four random replicates have been collected and rinsed through a $0.2 \mathrm{~mm}$ mesh of metal sieve in the field, then labeled and preserved for laboratory examination. Large organisms were easily sorted. The smaller mieobenthos form, is well visible and isolated under a low power dissecting microscope.

\section{Physico-chemical analysis}

The use of multi-field measurement device mobile Type WTW German origin, which measures all of the (temperature, salinity, dissolved oxygen, $\mathrm{pH}$ ) after calibration using standard solutions. The analysis of filtered water samples was carried out for the parameters, Sulphates (SO4), and Nitrate (NO3), indicator parameter [Dissolved Oxygen (DO). The samples were done according to standard methods APHA 1998. 


\section{Diversity indices and statistical analysis}

Biological indices such as Margalefs index (d); Shannonweiner index $(\mathrm{H})$ and Evenness index (E) were used in the calculation of taxa richness, diversity and evenness.

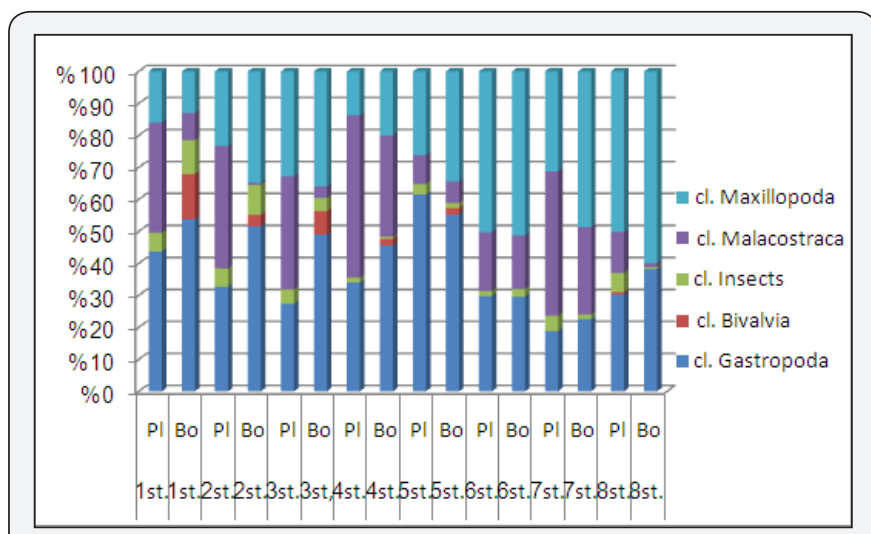

Figure 2 : Relative Abundance of invertebrates from aquatic plant in the intertidal area (PI) and from intertidal area without plant (bottom open sites) (Bo) in the shatt al-arab River.
To evaluate the distribution and diversity between sampling sites, community indices such as species richness, species abundant and Shannon diversity index were used SPSS Programs were conducted to evaluate significant differences of species abundance between sites and between seasons and relationship between invertebrate species and plant species richness (Figure 2).

\section{Results and Discussions}

A summary of annual average chemical and physical parameters along with stations characteristics and number of invertebrate taxa and plants species is presented in Table 1 (Figure 3). Aquatic invertebrate species richness was found to be correlated with plant species richness, but there was no correlation between plant richness and species of class Bivalvia and some species of class Gastropoda richness (Table 1) (Figure 4). Both plant species richness and invertebrate species richness showed negative correlations with some physical and chemical parameters in this study.

Table 1: Number of invertebrates and plants species and mean of some physiochemical parameters in study sites.

\begin{tabular}{|c|c|c|c|c|c|c|c|c|}
\hline Stations & $\begin{array}{c}\text { Invertebrates } \\
\text { Species No. }\end{array}$ & $\begin{array}{c}\text { Plant } \\
\text { Species No. }\end{array}$ & Temp. ${ }^{\circ}$ C & Salinity ppt & $\begin{array}{c}\text { Nitrate } \\
\text { (NO3) }\end{array}$ & $\begin{array}{c}\text { Phosphate } \\
\text { (P04) }\end{array}$ & $\begin{array}{c}\text { Dissolved } \\
\text { Oxygen (D0) }\end{array}$ & PH \\
\hline St. 1 & 28 & 10 & 20.89 & 1.18 & 25,12 & 0.378 & 8.23 & 8.27 \\
\hline St. 2 & 15 & 8 & 21.18 & 2.27 & 22.87 & 0.457 & 6.16 & 7.65 \\
\hline St. 3 & 24 & 10 & 22.65 & 2.46 & 19.59 & 0.357 & 5.73 & 7.92 \\
\hline St.4 & 16 & 9 & 23.88 & 3.65 & 17.73 & 0.589 & 6.35 & 7.72 \\
\hline St. 5 & 33 & 10 & 22.53 & 2.43 & 15.82 & 0.364 & 6.18 & 7.65 \\
\hline St. 6 & 16 & 6 & 24.71 & 2.84 & 16.68 & 0.295 & 5.10 & 7.32 \\
\hline St. 7 & 25 & 7 & 21.18 & 3.18 & 15.85 & 0.311 & 4.97 & 7.25 \\
\hline St. 8 & 12 & 4 & 23.26 & 4.34 & 14.75 & 0.274 & 5.04 & 7.29 \\
\hline
\end{tabular}

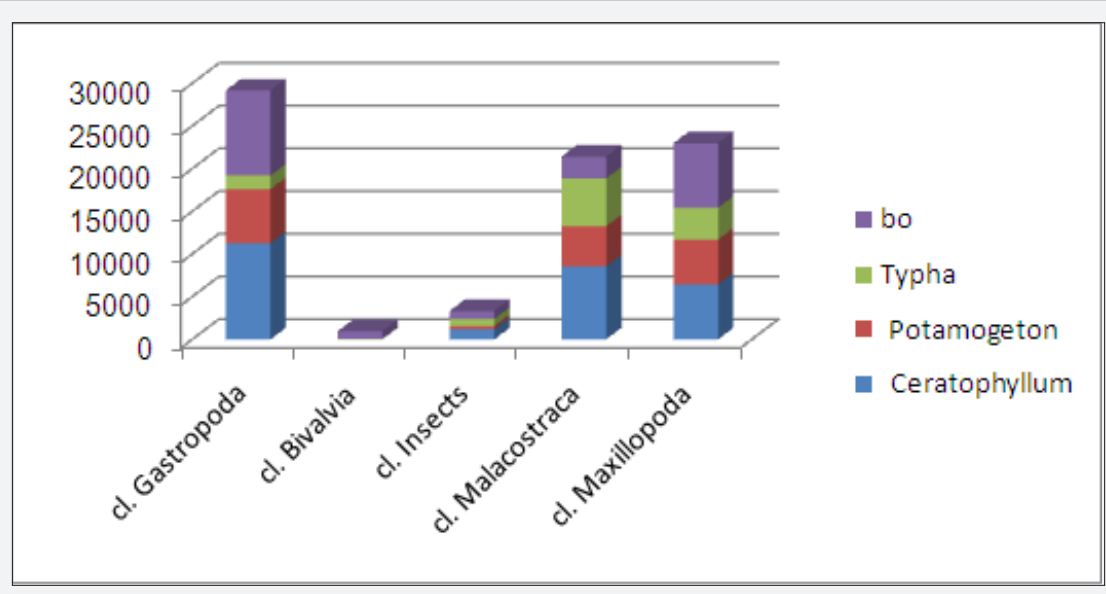

Figure 3 : The number of total organisms collected in each sites for four vegetation communities for during 2015. 


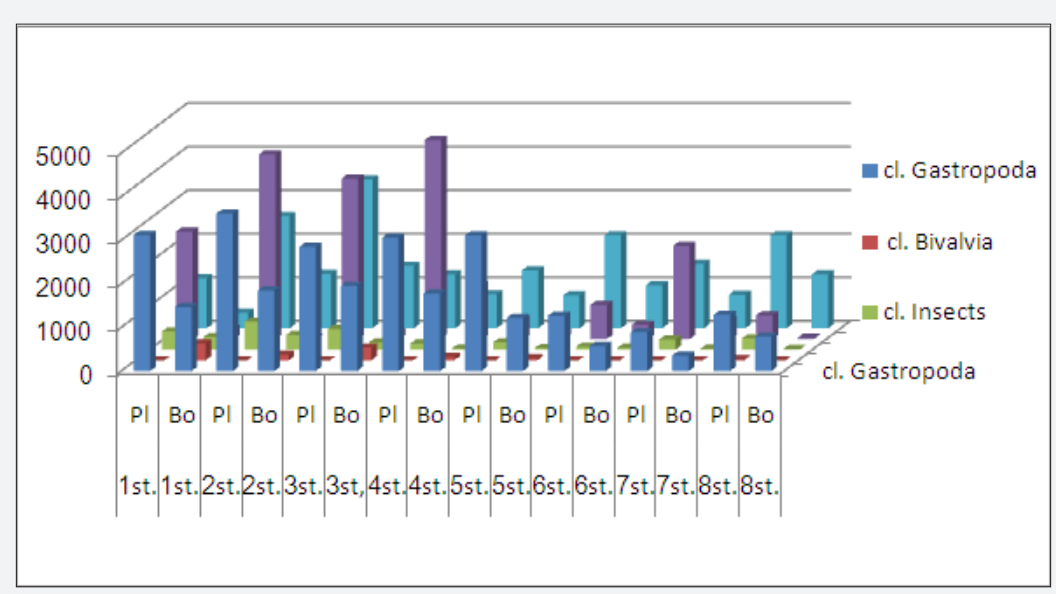

Figure 4 : Annual Density for main groups of invertebrates from aquatic plant in the intertidal area (PI) and from intertidal area without plant (bottom open sites) (Bo) in the Shatt Al-Arab River.

The mean values of nitrate in the water of study stations, during the period of this study, as recorded the highest concentrations of nitrate was amounted to 25.12 micrograms atom nitrogen / liter for first, while recorded the lowest reached 14.75 micrograms atom nitrogen / liter in the eight St. Phosphate ranged from 0.589 to 0.274 micrograms atom/ Liter at the four and eight station, respectively. PH ranged from 8.27 to 7.14 .6 at the first and seven stations, respectively. Dissolved oxygen concentrations ranged from 8.23 to $4.97 \mathrm{mg} / \mathrm{L}$ at the first and seven stations, respectively (Table 1).

Table 2 species composition of invertebrates and aquatic plants diagnosed and collected from the intertidal zone of Shatt
al-Arab during the study period in the all stations, from January 2015 until December 2015. Record presence most species of these stations in the study of Ranked and return 17 species of them to the phylum of mollusca consisting of 14 species representing 5 families of all belong to Class Gastropoda while 3 species representing two families belong to class bivalva and 20 species back to the phylum arthropoda contains 14 species belong to the class Malacostraca, including 5 species of shrimp and 4 species of cancers(crabs) and two species they return to each of two orders Amphipoda and Isopoda and one species of barnacles (class: maxillpoda) and 6 species belong to a class of insects.

Table 2: Species Composition of invertebrates and aquatic plant countered in the shatt al-arab River.

\begin{tabular}{|c|c|c|c|c|}
\hline Phylum & Class & Order & Family & Species \\
\hline \multirow{17}{*}{ Mollusca } & Gastropoda & Neotaeniglossa & Thiaridae & Melanoides tuberculata Műller, 1774 \\
\hline & & & Melanopsidae & Melanopsis nodosa Férussac, 1874 \\
\hline & & & & M. costata Oliver, 1804 \\
\hline & & & & M. subtingitana Annandale,1918 \\
\hline & & Architaenioglossa & Viviparidae & Bellamya bengalensis Lamark, 1822 \\
\hline & & Mesogastropoda & Ampullariidae & Pomacea canaliculata Lamarck, 1822 \\
\hline & & Littorinimorpha & Bithyniidae & Bithynia badiella Kűster, 1852 \\
\hline & & Archaeogastropoda & Assiminiadae & Assiminea mesopotamica n.-sp. \\
\hline & & Hygrophila & Planorbidae & Gyraulus convexiusculus Müller, 1774 \\
\hline & & & Lymnaeidae & Lymnaea (Radix )cor (Linnaeus, 1758 ) \\
\hline & & & & L. (Radix)auricularia (Linnaeus,1758) \\
\hline & & & Physidae & Physa acuta Draparnaud 1805 \\
\hline & & Neritacea & Neritidae & Theodoxus jordani Sowerby, 1832 \\
\hline & & & & Neritina violacea Gemlin, 1771 \\
\hline & Bivalvia & Veneroida & Corbiculidae & Corbicula fluminea Müller, 1774 \\
\hline & & Unionoida & & Corbicula fluminalis Müller, 1774 \\
\hline & & & Unionidae & Unio tigirdis Boubuignat, 1829 \\
\hline Arthropoda & Malacostraca & Amphipoda & Hyalidae & Parhyale basrensis Salman,1986 \\
\hline
\end{tabular}




\section{Oceanography \& Fisheries Open access Journal}

\begin{tabular}{|c|c|c|c|c|}
\hline & & & Talitridae & Platorchestia monodi stock, 1996 \\
\hline & & Isopoda & Cirolanidae & Annina mesopotamica Ahmed, 1971 \\
\hline & & & Sphaeromatidae & $\begin{array}{l}\text { Sphaeroma annandalei annandalei Stebbing, } \\
1911\end{array}$ \\
\hline & & Decapoda & Hymenosomatidae & Elamenopsis kempi Chopra and Das, 1930 \\
\hline & & & Sesarmidae & $\begin{array}{c}\text { Sesarma (Chiromantes) boulengeri Calman } \\
1920\end{array}$ \\
\hline & & & & Parasesarma sp. \\
\hline & & & Potamidae & Potamon sp. \\
\hline & & & Palaemonidae & $\begin{array}{l}\text { Macrobrachium nipponense de Haan, } 1849 \\
\text { Palaemon elegans Rathke,1852 }\end{array}$ \\
\hline & & & Atyidae & $\begin{array}{l}\text { Caridina babaulti basrensis Al-Adhub \& } \\
\text { Hamzah, } 1987\end{array}$ \\
\hline & & & & Atyaephyra desmaresti Millet, 1831 \\
\hline & & & Penaeidae & $\begin{array}{c}\text { Metapenaeus affinis H. Milne-Edwards, } \\
1837\end{array}$ \\
\hline & & Mysida & Mysidae & $\begin{array}{l}\text { Indomysis nybini Biju \& Panampunnayil, } \\
2010\end{array}$ \\
\hline & $\begin{array}{l}\text { Maxillopoda } \\
\text { Cirripeda }\end{array}$ & Thoracica & Balanidae & Balanus amphitrite amphitrite Darwin, 1854 \\
\hline & Insecta & Diptera & Chrionomidae & Chironomous sp. \\
\hline & & Coleoptera & Dytiscidae & Colymbetes sp. \\
\hline & & Hemiptera & $\begin{array}{l}\text { Corixidae } \\
\text { Belostomatidae }\end{array}$ & $\begin{array}{l}\text { Sigara sp. (Water Boatmen). Belostoma } \\
\text { cardofanum.( Giant Water Bug) }\end{array}$ \\
\hline & & Odonata & Coenagrionidae & $\begin{array}{l}\text { Damselflies Ischnura evansi (Morton, 1919) } \\
\text { larvae }\end{array}$ \\
\hline & & & Libellulidae & $\begin{array}{c}\text { Dragonfly Brachythemis fuscopalliata (Selys, } \\
\text { 1887). Larvae }\end{array}$ \\
\hline \multirow[t]{10}{*}{ Kingdom: Plantae } & Angiosperms & & Ceratophyllaceae & Ceratophyllum demersum \\
\hline & & & Potamogetonaceae & Potamogeton crispus \\
\hline & & & Hydrocharitaceae & Vallisneria spiralis \\
\hline & & & Poaceae & Phragmites australis \\
\hline & & & Typhaceae & Typha domingensis \\
\hline & & & Poaceae & Paspalumpas paspaloides \\
\hline & & & Plantaginaceae & Bacopa monniera \\
\hline & & & Juncaceae & Juncus rigidus \\
\hline & & & Cyperaceae & Cyperus malaccensis \\
\hline & Filicopsida & & Salviniaceae & Salvinia natans \\
\hline
\end{tabular}

A total of 77866 individuals and 37 invertebrates lower taxa were found, pertaining to five higher taxa (classes) (Gastropoda, Bivalvia, Malacostraca, Maxillopoda and Insecta). With 22 taxa and $61.32 \%$ of the total invertebrate numbers, phylum Arthropoda were the dominant by species Balanus amphitrite amphitrite were most common, comprising $48.16 \%$ of all the phylum Arthropoda specimens were collected. Main groups of aquatic invertebrate were consisting Gastropoda $37.46 \%$ bivalve $1.22 \%$ and were next, with crustacea (Malacostraca $27.50 \%+$ Maxillopoda $29.52 \%$ ) followed by Insects (4.27 \%) (Figure 2).

The Figure 4 shows marked differences in the density of main groups invertebrate among those present on the Aquatic plants and with those in the sediment at eight stations in this study, where the density organisms located in or on aquatic plants was higher than on the bottom for the two groups of crustaceans and insects exception of a group of bivalve in phylum Mollusca and some species in group Gastropoda, which was ringed with a higher density on the sediment and most of the months of the study.

Diversity, dominance, and species richness indices calculated for the eight stations are shown in Table 3. Taxa richness calculated as: Margalef's indexes (d) were highest median value in st. 2, (3.82), while least median value accounted for the highest richness (2.12) (Figure 5). 


\section{Oceanography \& Fisheries Open access Journal}

Table 3: Median values of Diversity Indices of invertebrates in the intertidal shores of Shatt-Al-Arab River.

\begin{tabular}{|c|c|c|c|c|c|c|c|c|}
\hline Indices & St. 1 & St. 2 & St. 3 & St. 4 & St. 5 & St. 6 & St. 7 & St. 8 \\
\hline $\begin{array}{c}\text { Margalef } \\
\text { Diversity (D) }\end{array}$ & 2.34 & 3.56 & 2.95 & 3.82 & 2.4 & 2.15 & 2.26 & 2.12 \\
\hline $\begin{array}{c}\text { Shannon } \\
\text { Weiner (H) }\end{array}$ & 1.84 & 3.46 & 2.25 & 3.17 & 2.16 & 1.74 & 1.63 & 1.57 \\
\hline Evennees (E) & 0.62 & 0.82 & 0.71 & 0.91 & 0.73 & 0.67 & 0.61 & 0.59 \\
\hline
\end{tabular}

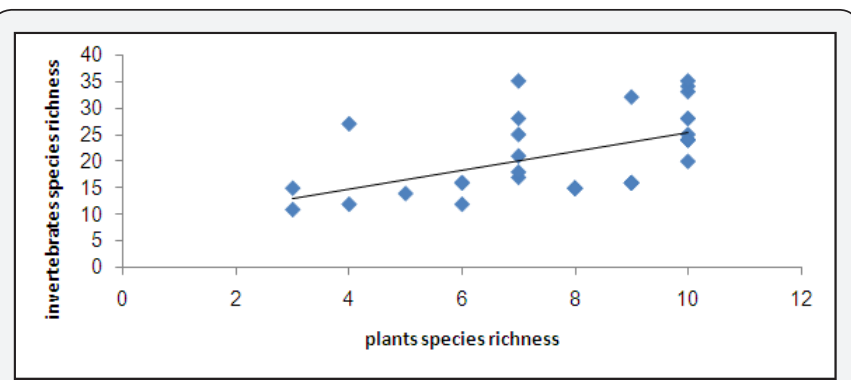

Figure 5 : Correlation between the number of invertebrate species and the number of plant species in eight sites at Shatt Al-Arab $\left(n=32, r^{2}=0.67, p<0.05\right)$. for all seasons in this study.

The relationships of physical structure, water quality and plant communities with aquatic invertebrates (benthic macroinvertebrates) assemblages all showed similar patterns, with samples from eight Sites forming a separate and small variable groups. The variability in the eight sites that we studied was associated with the spatial heterogeneity between sites and within each site. Seasonality usually reported [9,24]. Most populations were greatest at the beginning of the summer and declined as the summer progressed with the exception of those organisms with a longer development period such as Lepidoptera and Trichoptera.

Our data suggest a high variability of numbers within the populations of invertebrates. This high variability of invertebrate populations has been noted before by Rosine [25] \& Krull [26] and can be explained by a number of causes including normal die off, hatching of eggs, pupation, emergence, and patterns of predation, local movements and uneven distribution.

In conclusion, it is important to recognize the role that plant communities play in supporting macroinvertebrate populations with possible implications for water bodies management practices. The present study suggests that there are qualitative and quantitative differences in macroinvertebrate abundance and diversity among different vegetation communities [27-29].

The plant species composition tends to play a larger role in the distribution of invertebrates as documented by Krecker $[8,30]$. Mean diversity was significantly different between vegetation types. The Typhasites supported the most diverse populations of invertebrates and the open sites produced the least diverse populations. We attribute this difference to the greater surface area provided by the vegetation types $[6,31,32]$. Increased surface area of vegetation may provide protection from predators [33] and more substrate for growth of periphytic algae, which is an important food source of many invertebrates [34]. Invertebrates utilize plants as a direct food source, sites for oviposition, and sources of respiratory oxygen [35]. In this study, invertebrate populations displayed seasonal trends similar to those previously [36-39].

\section{References}

1. Rosenberg DM, VH Resh (Eds) (1993) Freshwater Biomonitoring and Benthic Macroinvertebrates. Chapman and Hall, York, England, pp. $1-194$.

2. Sharma C, JS Rawat (2009) Montoring of aquatic macroinvertebrates as bioindicator for assessing the health of wetlands: A case study in the central Himalayas, India. Ecological Indicators 9: 118-128.

3. Kazanci N, M Dugel (2000) Ordination and classification of macroinvertebrates and environmental data of stream in Turkey. Water Sci Technol 47(7-8): 133-139.

4. Berg CO (1949) Limnological relations of insects to plants of the genus Patamogeton. Transactions of American Microscopical Society 68: 279-291.

5. McGaha YJ (1952) The limnological relations of insects to certain aquatic flowering plants. Transactions of American Microscopical Society 71(4): 355-381.

6. Krull JN (1970) Aquatic plant-macroinvertebrate associations and waterfowl. Journal of Wildlife Management 34(4): 707-718.

7. Soszka GJ (1975) Ecological relations between invertebrates and submerged macrophytes in the lake littoral. Ekol Pol 23: 393-415.

8. Gerrish N, JM Bristow (1979) Macroinvertebrate associations with aquatic macrophytes and artificial substrates. J Great Lakes Res 5: 6971.

9. Chilton EW (1990) Macroinvertebrate communities associated with three aquatic macrophytes (Ceratophyllum demersum, Myriophyllum spicatum, and Vallisneria americana) in Lake Onalaska, Wisconsin. Journal of Freshwater Ecology 5: 455-466.

10. Hassall C, Hollinshead J, Hull A (2011) Environmental correlates of plant and invertebrate species richness in ponds. Biodiversity and Conservation 20(13): 3189-3222.

11. Krull JN (1970) Aquatic plant-macroinvertebrate associations and waterfowl. Journal of Wildlife Management 34(4): 707-718.

12. Al Obaidi GS (2006) Study of phytoplankton community in Abo Zirig Marsh, Souhtern Iraq MSc thesis. University of Baghdad, Iraq, pp. 116.

13. Ali AH, Aziz NM, Hamza HA (2007) Abundance, occurrence, seasonal changes and species composition of Macroinvertebrates in the restored Iraqi southern marshes. Marsh Bulletin 2(1): 80-95.

14. Hassan KS, Habeeb MA, Al Mousawi NJ (2000) Occuremce of aquatic insects with Algae in basrah province. Marina Mesopotamica 15(1): 137-143.

15. Naser MD, Yasser AG Al Khafaji, Kh Aziz N, Gmais S (2008) The Genus Lymnaea (Lamarck, 1799) from southern mesopotamica: are the morphological and anatomical studies enough to solve its complexity? 
Marina Mesopotamica 23(2): 349-362.

16. Hussain NA, Ali AH, Lazem LF (2012) Ecological indices of key biological groups in Southern Iraqi marshland during 2005-2007. Mesopot J Mar Sci 27(2): 112-125.

17. Salman DS, Abbas MF, Akaash AN (2010) Distribution and abundance of Cladocera in Southern Iraqi marshes. Abstracts of Conference on Biological Diversity, Marine Science Centre, Basrah Univ, Iraq, p. 37.

18. Dudgeon D, Arthington AH, Gessner MO, Kawabata Z, DJ Leveque (2006) Freshwater biodiversity: Importance, threats, status and conservation challenges. Biol Rev Camb Philos Soc 81(2): 163-182.

19. Ali MH, Salman SD (1987) Growth and production of the amphipod Parhyale basrensis (Talitridae) in the Shatt Al-Arab region. Mar Ecol Prog Ser 40: 231-238.

20. Ahmed MM (1975) Systematic study on the mollusca from Arbian Gulf and Shatt Al-Arab. Center for Arab Gulf studies, Basrah Univ. Iraq, p. 87.

21. Al Adhub AHY, Hamzah HA (1987) Caridina babaulti basrensis sub sp. Nov. from the Shatt Al-Arab Region, Iraq (Decapoda: caridea, Atyidae). Crustceana 52(3): 225-228.

22. Frandsen F (1983) A field guide to freshwater snails in countries of the WHO eastern Mediterranean region. Danish Bilharziasis Laboratory, Africa, pp. 45.

23. Al Mayah, Abud Rathaa Akbar, Al Saadi, Hussien Ali (1983) water plant in Iraq. Studies center of Arabian Gulf. Basrah University, Iraq, pp. 735.

24. Gregg WW, FL Rose (1985) Influence of aquatic macrophytes on invertebrate community structure, guild structure, and micro distribution in streams. Hydrobiologia 128(1): 45-56.

25. Rosine WN (1955) The distribution of invertebrates on submerged aquatic plant surfaces in Muskee Lake, Colorado. Ecology 36(2): 308314.

26. Krull JN (1970) Aquatic plant-macroinvertebrate associations and waterfowl. Journal of Wildlife Management 34(4): 707-718.

27. Wetzel RG (2001) Limnology. Lake and River Ecosystems. Academic Press, San Diego, USA, pp. 1006.
28. Sullivan PE, Reynolds CS (2004) The Lakes Handbook: Limnology and Limnetic Ecology, Volume 1: Blackwell Publishing, Oxford, UK, pp. 699.

29. Lampert W, Sommer U (2007) Limnoecology. The Ecology of Lakes and Streams. Oxford University Press, England, pp. 333.

30. Krecker FH (1939) A comparative study of the animal population of certain submersed aquatic plants. Ecology 20: 553-562.

31. McGaha YJ (1952) The limnological relations of insects to certain aquatic flowering plants. Transactions of American Microscopical Society 71(4): 355-381.

32. Downing JA (1981) In Situ foraging responses of three species of littoral cladocerans. Ecological Monographs 51(1): 85-103.

33. Dvorak J, EPH Bestz (1982) Macroinvertebrate communities associated with the macrophytes of Lake Vechten: structural and functional relationships. Hydrobiologia 95(1): 115-126.

34. Rooke JB (1984) The invertebrate fauna of four macrophytes in a lotic system. Freshwater Biology 14(5): 507-513.

35. Beckett DC, Aartila TP, Miller AC (1991) Invertebrate abundance on Potamogeton nodosu: Effects of plant surface area and condition. Canadian Journal of Zoology 70 (2): 300-306.

36. Harrod JJ (1964) The distribution of invertebrates on submerged aquatic plants in chalk stream. Journal of Animal Ecology 33(2): 335348 .

37. Krapu GL (1979) Nutrition of female dabbling ducks during reproduction in, TA Bookhout (Eds). Waterfowl and wetlands- An integrated review. Proc Symp North Cent Sect, The Wildl Soc P. 59-70.

38. Richardson JS, RJ Danehy (2007) A synthesis of the ecology of headwater streams and their riparian zones in temperate forests For Sci 53(2): 131-147.

39. Al Dabbagh KY, Daoud YT (1985) The ecology of three gastropod mollusks from Shatt Al-Arab [Iraq]. Journal of Biological Sciences Research 16: 155-168.
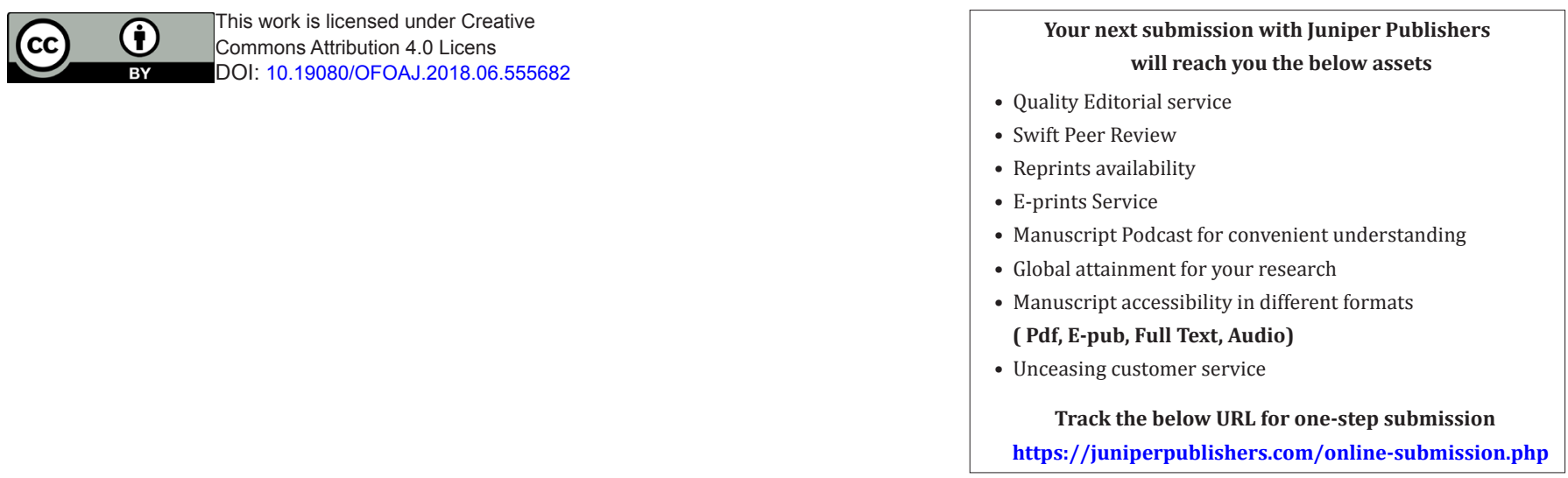